\title{
ВДОСКОНАЛЕННЯ ОЦНКИ ВПЛИВУ БАЗОВИХ ІНСТИТУТІВ НА РОЗВИТОК ВИДАВНИЧО-ПОЛІГРАФІЧНОЇ ДІЯЛЬНОСТІ
}

\begin{abstract}
У статті розглянуто інвестиційну привабливість видавничо-поліграфічної галузі Украӥни та ї̈ регіонів, сучасний стан і стратегію розвитку корпоративного управління підприємств видавничо-поліграфічної галузі (ВПГ), проведено дослідження трансформачії видавничого та поліграфічного підприємництва, внаслідок якої видавничо-поліграфічний комплекс перетворився у ВПГ, а виробниче підприємництво в поліграфії набуло функиій сфери обслуговування видавництв, як ие i прийнято у світовій видавничій практиці. Розкрито можливості провідних підприємств регіону та встановлено, щуо серед усіх моделей розвитку видавничих $і$ поліграфічних підприємств найперспективнішою щодо вкладення інвестицій можна вважати модель, згідно з якою видавництва мають власну поліграфічну базу.
\end{abstract}

Ключові слова: базові інститути, інституційна теорія, фактори економічного зростання, корпоративне управлінн, конкурентоспроможність, видавничо-поліграфічна діяльність.

Постановка проблеми. Сучасна ситуація в економіці України та їі регіонів характеризується динамічною трансформацією форм господарювання, перерозподілом власності та пошуком найбільш ефективних організаційних підходів формування і використання корпоративного управління, що досить широко використовується у західній теорії і практиці господарювання i достатньо швидко запроваджується у вітчизняний економіці [1]. Це зумовило поширення корпоративної власності і управління, стрімкий розвиток концентрації акціонерного капіталу.

Ринкові механізми проникли в регулювання економічних проблем, ресурсообіг, сфери виробництва, розподілу та споживання.

Видозмінюються як методологія, так і методичні підходи теоретичних досліджень поведінки різних господарюючих суб'єктів, відбувається 3 об'єктивних причин адаптація вітчизняної економіки до сучасних умов функціонування.

Ринкова система господарювання в значній мірі пов'язана 3 підприємницькою активністю в усіх сферах економіки, а іiі зростання $\epsilon$ перспективним аспектом конкурентно-ринкового середовища. Основною метою усіх суб'єктів ринкової економіки, зайнятих підприємництвом, $€$ отримання прибутку, який відображає всі сторони господарської діяльності підприємства; актуально це i для видавничо-поліграфічної галузі.

(C) Палига Свген Миколайович, д.е.н., професор кафедри підприємництва та маркетингу, Українська академія друкарства, м. Львів

Циганко Людмила Анатоліївна, магістрант, Українська академія друкарства, м. Львів, email: kafekonomikauad@gmail.com
Видавничо-поліграфічна діяльність $\epsilon$ складовою інформаційної, духовно-культурної та економічної сфер суспільства. Друкована продукція, поліграфічні роботи та послуги відіграють важливу роль та знаходять своє місце на споживчому ринку. Внутрішній національний ринок видавничої та друкованої продукції формується під впливом взаємодії споживчого попиту і товарної пропозиції [2].

У цьому аспекті, на нашу думку, необхідно приділити значну увагу впливу базових інститутів на розвиток видавничо-поліграфічної діяльності через завершеність інституційних змін ВПД регіонів України, формуванні методології оцінки інституційних впливів на функціонування та розвиток ВПД та дослідження системи інституційних факторів оцінки складної виробничої системи адаптації запропонованих підходів взаємопов'язаних груп факторів 3 метою побудови системи факторів впливу базових інститутів на оцінку ефективності функціонування ВПД.

Аналіз останніх досліджень і публікацій. Проведений огляд праць щодо оцінки економічного зростання свідчить про недостатню увагу щодо вивчення специфіки розвитку окремих галузей на основі інституційних чинників, як у загальнонаціональному, так, і в регіональному розрізі. Крім того, розвиток сучасної інституційної економічної теорії свідчить, що відбувається постійне ускладнення внутрішніх і зовнішніх зв'язків між суб'єктами ринку, внаслідок чого, вплив інституційної складової на економічне зростання значно посилюється. Отже, вагомим чинником державної політики стимулювання економічного розвитку має стати визначення пріоритетів трансформації інституційного 
середовища на галузевому рівні із врахуванням регіональних особливостей [3].

Важливим $є$ те, що дане середовище формує стійкі моделі поведінки галузевих суб'єктів, у межах яких проводиться виробничогосподарська діяльність. Підтвердження даних припущень простежується у працях науковців. Так, М. В. Головко вважає, що: «Результативність управління будь-якою сферою національної економіки напряму залежить від якості сформованого інституційного середовища, його адекватності щодо ріння розвитку соціально-економічних і виробничих відносин у суспільстві. Окрім чого, інституційні фактори формують обмеження та стимули, які спонукають галузеві суб'єкти підвищувати свою ефективність, i як наслідок, забезпечують загальний розвиток економіки та суспільства. Як зазначає у своїй праці Е. Аморос: "Розвиток підприємництва, є результатом людської поведінки та інституційного середовища».

Враховуючи важливість впливу інституційних факторів на функціонування ВПД, потрібно розглянути та проаналізувати наявні методологічні підходи щодо оцінки їх впливу як на загальнодержавному, так і на рівні окремого регіону. Однак, враховуючи те, що перелічені фактори перебувають у кореляції один 3 одним, це спричиняє деякі методологічні складнощі дослідження їх впливу на зростання окремих галузей [4].

Зважаючи на предмет наших досліджень, слід зазначити про оцінку впливу інституційних факторів на ВПД через призму теорії виробництва. Розгляд інституції як ендогенного виробничого фактора дає змогу перейти до формування відповідного категоріального апарату i методики вимірювання впливу інституційних факторів на розвиток ВПД. Однак доробок праць, присвячених поєднанню традиційних методик оцінювання ефективності виробничої діяльності та альтернативних підходів, що сформувалися під впливом інституційної теорії, $є$ значно обмеженим.

Існують підходи щодо ототожнення інституційних факторів, резервів, ресурсів тощо. Це призводить, на нашу думку, до недостатньо обгрунтованих висновків, що «деякі інституційні умови формуються всередині індивідуального виробництва і повинні розглядатися 3 точки зору відповідності вимогам активізації діяльності». Однак навряд чи обставини функціонування системи зможуть формуватися в їі межах, скоріш за все це функція зовнішнього середовища.

Цікавою $з$ позиції дослідження інституційних впливів є концепція економічної соціодинаміки, подана Р.Грінбергом i А. Рубінштейном.
Авторами в рамках проведених досліджень запропонована оригінальна модель «соціодинамічного мультиплікатора економічного зростання», який фактично $\epsilon$ інституційним мультиплікатором, оскільки, саме інститути забезпечують необхідне поєднання власної креативної енергії з перевагами розвитку суспільства, внаслідок чого запуск механізму цього мультиплікатора стає неминучим. У рамках концепції інститути розглядаються каталізатором економічної мультиплікації, що дає змогу виокремити інституційний акселератор, в основі якого міститься принцип взаємозв'язку між інституційними змінами та економічним розвитком. Однак недоліком $\epsilon$ відсутність повною мірою сформованого методологічного апарата оцінки впливу інституційного чинника на економічний розвиток, а вся основна увага зосереджена на дослідженні механізму їх взаємозв'язку. Отож можна стверджувати, що застосовувані підходи економічних вимірювань дуже різнопланові та не завжди повною мірою враховують інституційні параметри виробництва [5].

Формулювання цілей статті. Мета статті обгрунтування оцінки впливу базових інститутів на розвиток видавничо-поліграфічної діяльності регіонів України.

Опис основних результатів дослідження. Розглянемо найпоширеніші методологічні підходи, що використовуються для оцінки інституційних впливів на виробничі відносини ВПД. Найпоширеніший підхід до оцінки впливу інституційних факторів на функціонування різних секторів економіки грунтується на теорії трансакційних витрат та на значній кількості різнобічних підходів щодо їх оцінки [6].

Так, Д. Фролов у своїх дослідженнях дотримується думки, що будь-який продукт наділений певним статусом, який відображає імідж його виробника i, як наслідок, статусний компонент має вагоме значення при формуванні ціни товару. За таких умов стає очевидним, що іиституційна складова $є$ невід'ємною частиною виробничого процесу та формування статусу продукту. Автор стверджує, що як і виробничий, інституційний процес зумовлює відповідні витрати, які спричинені формуванням статусів певних видів продукції на рівні підприємства, регіону та галузі. Ці витрати інституційного капіталу, або інституційні витрати, являють собою елемент трансакційних витрат, які одночасно iз трансформаційними становлять загальні витрати виробництва [8].

Відповідно до даної теорії до найпоширеніших видів інституційних витрат належать: 
- пов'язані із отриманням дозвільних документів на виробництво продукції (ліцензій, дозволів, придбання або розробку патентів, оформлення прав власності тощо);

- зумовлені проведенням сертифікації продукції та впровадженням систем якості виробництва;

- витрати представницького характеру (участі у конкурсах, виставках, різних громадських заходах тощо);

- пов'язані із нормуванням та стандартизацією виробничих процесів і операцій;

— витрати щодо здійснення контролю якості продукції та зумовлені iї браком;

— витрати щодо моніторингу діючих контрактів;

— зумовлені особливостями внутрішньої дозвільної системи (дозволи, погодження, врегулювання внутрішньовиробничих протиріч тощо);
- пов'язані із контролем за дотриманням працівниками виконуваних ними функцій, встановлених правил та стандартів (виявлення ухиляння від службових обов'язків, порушень внутрішнього розпорядку техніки безпеки, технологій виробництва тощо [7].

Розвиваючи цей підхід, для виявлення зв'язків між різними системами інститутів, доцільно виокремити комплексні інституційні структури цих систем i в подальших дослідженнях розглянути їх компліментарність. Для цього, зважаючи на особливості ВПД, цікавим є підхід запропонований Т. Холлізвортом, який акцентує увагу на відмінностях у взаємодії технологічних та галузевих виробничих систем.

На основі зазначених досліджень запропоновано систему інституційних факторів оцінки складної виробничої системи (рис. 1). Тобто ця система була сформована відомими вченими, на дослідження яких ми опиралися в даній статті.

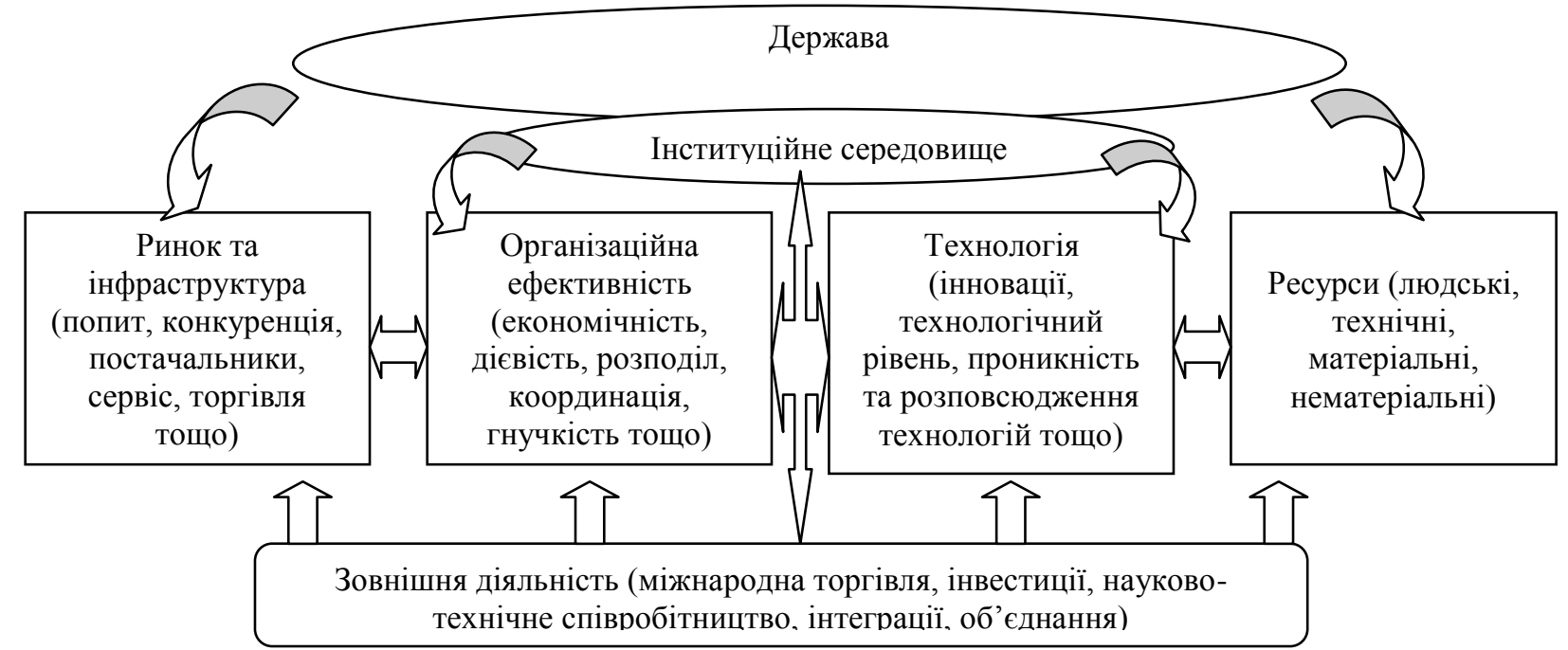

\section{Рис. 1. Система інституційних факторів економічного зростання виробничих систем* *Розроблено авторами}

Для дослідження впливу базових інститутів на функціонування та економічний розвиток ВПД регіону 3 урахуванням принципу компліментарності, вважаємо за необхідне систематизувати показники оцінки впливу інституційного середовища на діяльність, першочергово на виробничу складову, дослідити ix взаємозв'язок із групами факторів економічного зростання та розглянути систему компліментарності базових інститутів ВПД.

Однак, насамперед, потрібно систематизувати основні фактори інституційного впливу на ВПД регіону, а вже пізніше формувати комплексну методику їх оцінки. Для досягнення поставлених цілей найповніше, на нашу думку, підходить класифікація фінського
Т. Хамалайнена. Відповідно до цього підходу запропоновано такі взаємопов'язані групи факторів, які оцінюють конкурентоспроможність та зростання в складних економічних системах. Внаслідок чого виникає потреба в адаптації запропонованих підходів до особливостей ВПД (рис. 2).

Оскільки механізми впливу різних інституційних систем на економічне зростання мають значні відмінності, значущість підходу, запропонована $\mathrm{T}$. Холлізвортом полягає в розподілі інституційних структур за ступенем їх стабільності, що включає в себе такі рівні: інститути; інституційні механізми; інституційні галузі; організації; формальне закріплення (закони) та продуктивність. 


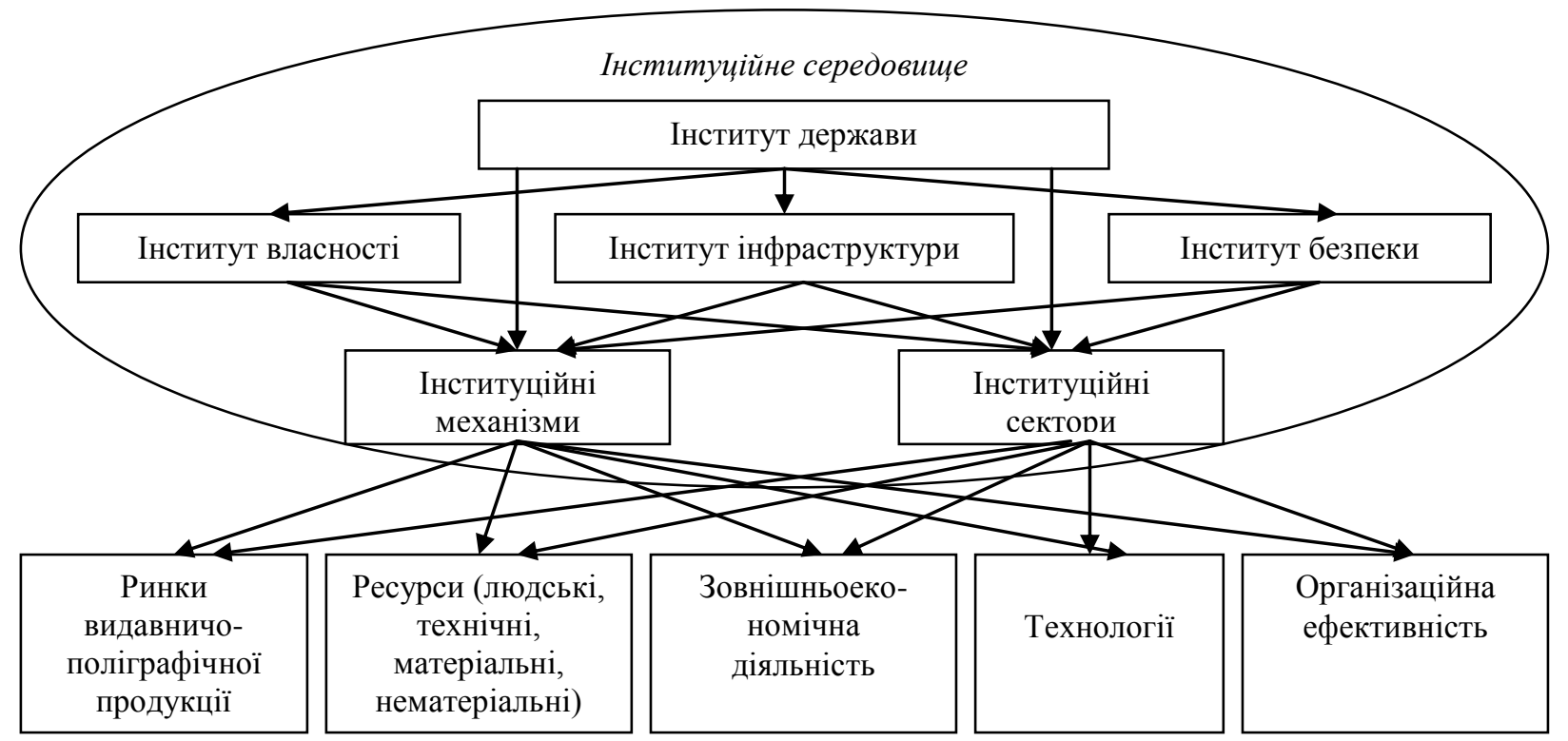

Рис. 2. Система оцінки впливу факторів базових інститутів ефективності функціонування ВПД*

*Розроблено авторами

Зважаючи на врахування галузевих та регіональних особливостей, запропоновані підходи Т. Хамалайнена та T. Холлізворта можуть бути адаптовані для інституційного аналізу ВПД та побудови системи оцінки впливу інституційних факторів на економічне зростання діяльності на загальнодержавному та регіональному рівнях. Однак, на нашу думку, використання показника інституційної стабільності як критерію диференціації $\epsilon$ складним, оскільки стабільність залежить від великої кількості контекстних умов та інституційних зв'язків.

Враховуючи вищезазначену складність, пропонуємо обмежитися побудовою комплексної системи факторів оцінки впливів базових інститутів на функціонування ВПД на загальнодержавному та регіональному рівнях та запропонувати методологічний підхід щодо формування інтегрованого показника сучасних досліджень інституційного середовища. Доведено, що існування певних типів структури інституційного середовища $€$ наслідком комплементарності іiі компонентів, тобто на основі досліджень відомих вчених та науковців і фахівців поліграфії в Україні $\epsilon$ необхідність у завершеності інституційних змін ВПД в регіоні через вплив, як показано на рис. 2, інститутів власності, інфраструктури, безпеки, інституційні механізми та сектори через ефективне використання наявних ресурсів, ринків ВПД, технологій, організаційної ефективності та зовнішньоекономічної діяльності [9].

Висновки i перспективи подальших досліджень. Отримані результати свідчать про незавершеність інституційних змін ВПД регіонів України. Так, враховуючи складність інституційного аналізу, різноманітність методологічних підходів щодо його проведення, значну кількість інституційних зв'язків, регіональних та загальнодержавних галузевих особливостей ВПД релевантно оцінити вплив інституційних факторів на функціонування діяльності є надзвичайно складно. Це зумовлює потребу формування методології оцінки інституційних впливів на функціонування діяльності, що грунтуватиметься на системі 3 трьох груп інтегрованих показників: індикаторів оцінки інституційного розвитку держави; узагальнюючих показників оцінки інституційних змін у ВПД та часткових показників оцінки впливу базових інститутів на функціонування діяльності в окремих регіонах і подальших досліджень оцінки впливу базових інститутів.

\section{ПЕРЕЛІК ВИКОРИСТАНИХ ДЖЕРЕЛ}

1. Ансофф И.Х. Новая корпоративная стратегия / Ансофф И.Х. СПб: Питер, 2004. — 416 с.

2. Базилюк В.Б. Інституційне середовище механізму управління поліграфічними підприємствами / В.Б. Базилюк // Вісник соціально-економічних досліджень. — 2014. — №3(54). — С. 74-78.

3. Економіка України: стратегія і політика довгострокового розвитку / [В.М. Геєць та ін.] — К.: Ін-т прогнозування НАН України; Фенікс, 2003. — 1008 с. 
4. Мікула Н.А. Регіональний видавничо-поліграфічний кластер: моногр. / Н.А. Мікул, С.М. Палига, В.Б. Базилюк. - Львів: Ліга-Прес, 2013. - 172 с.

5. Палига Є.М. Корпоративне управління та фондовий ринок. Підручник / Є.М. Палига, I.Є. Палига. Львів: УАД, 2017. - $506 \mathrm{c.}$

6. Пономаренко В.С. Стратегія розвитку підприємства в умовах кризи: Моногр. / Пономаренко В.С., Тридід О.М., Кизим М.О. - Х.: ВД «ІНЖЕК», 2003. - 328 с.

7. Раєвнєва О.В. Управління розвитком підприємства: методологія, механізм, моделі: Моногр. / Раєвнєва О.В. — Х.: ВД «НЖЕК», 2006. — 496 с.

8. Фролов Д.П. Эволюционная перспектива институциональной экономики России: монор. / Д.П. Фролов. Волгоград: Из-во ВолГУ, 2008. - 462 с.

9. Інституціонально-інформаційна економіка: підручник [Електронний ресурс] / Чухно А.А., Юхименко П.І., Леоненко П.М. — К., 2010. — Режим доступу: http://westudents.com.ua/glavy/18963-rinki-y-obmn.html

10. Швайка Л.А. Розвиток і регулювання видавничого підприємництва: моногр. / Л.А. Швайка. - Львів: Укр. акад. друкарства, 2005. - 432 с.

\section{REFERENCES}

1. Ansoff I.H. (2004). Novaia korporatyvnaia stratehyia [New corporate strategy]. Saint Petersburg : Piter. [in Russian].

2. Bazyliuk V.B. (2014). Instytutsiine seredovyshche mekhanizmu upravlinnia polihrafichnymy pidpryiemstvamy [The institutional environment of the management of printing enterprises]. Visnyk sotsialno-ekonomichnykh doslidzhen - Bulletin of socio-economic researches, №3 (54), 74-78.

3. Heiets V.M., \& oth. (2003). Ekonomika Ukrainy: stratehiia i polityka dovhostrokovoho rozvytku [Economy of Ukraine: strategy and policy of long-term development]. Kyev: Institute of Forecasting of NAS of Ukraine; Fenix. [in Ukrainian].

4. Mikula N.A., Palyha Ye.M., \& Bazyliuk V.B. (2013). Rehionalnyi vydavnycho-polihrafichnyi klaster [Regional publishing and printing cluster]. Lviv: Liha-Pres. [in Ukrainian].

5. Palyha Ye.M., \& Palyha I.Ye. (2017). Korporatyvne upravlinnia ta fondovyi rynok [Corporate governance and stock market]. Lviv: UAP. [in Ukrainian].

6. Ponomarenko V.S., Trydid O.M. \& Kyzym M.O. (2003). Stratehiia rozvytku pidpryiemstva v umovakh kryzy [Strategy of development of the enterprise in the conditions of crisis]. Kharkiv: PH "Inzhek". [in Ukrainian].

7. Raievnieva O.V. (2006). Upravlinnia rozvytkom pidpryiemstva: metodolohiia, mekhanizm, modeli [Management of enterprise development: methodology, mechanism, models]. Kharkiv: PH "Inzhek". [in Ukrainian].

8. Raievnieva O.V. (2008). Upravlinnia rozvytkom pidpryiemstva: metodolohiia, mekhanizm, modeli [Evolutionary perspective of the institutional economy of Russia]. Volgograd: VSU Publishing House. [in Russian].

9. Chukhno A.A., Yukhymenko P.I., \& Leonenko P.M. (2010). Instytutsionalno-informatsiina ekonomika [Institutional and informational economy]. Retrieved from http://westudents.com.ua/glavy/18963-rinki-y-obmn.html. [in Ukrainian].

10. Shvaika L.A. Rozvytok i rehuliuvannia vydavnychoho pidpryiemnytstva (2005). [Development and regulation of publishing business]. Lviv: Ukrainain academy of printing. [in Ukrainian].

Одержано 15.03.2018 p. 